\title{
Clinicopathological Features of Triple Negative Breast Cancer: A Perspective Analysis
}

\author{
Dr. Sumita A. Jain, Dr. Shanti Lal Jeengar, Dr.Lakshman Agrawal, \\ Dr.Bharathi Mohan, Harish Kaknale, Dr. Devendra Singh Mandal, Dr.Pramod \\ Chandolia, Dr. Anil Kumar Khyalia, Dr. Pankaj Somani
}

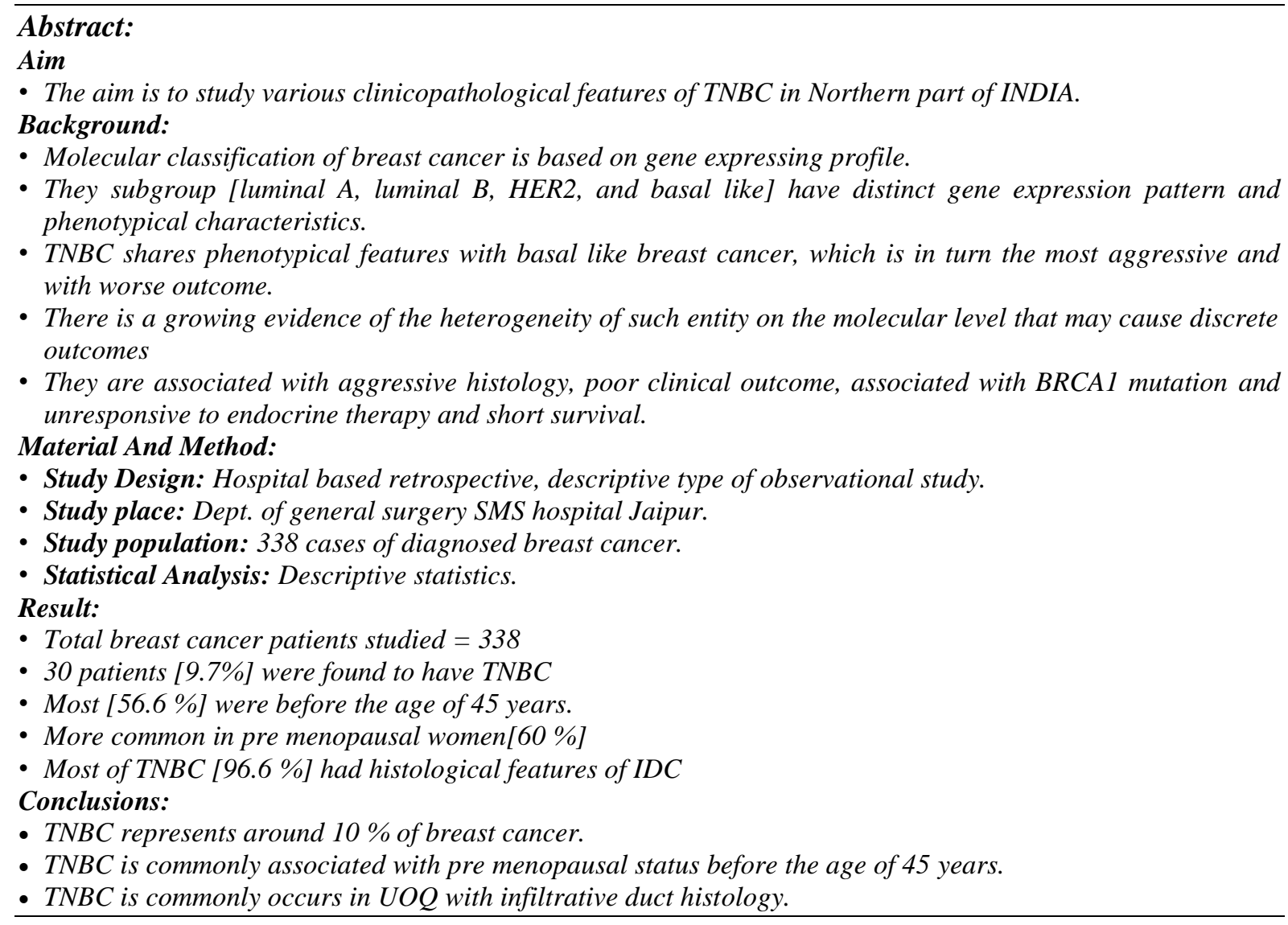

\section{Introduction}

Only a decade ago, breast cancer was considered a relatively 'simple' disease in many respects, with focus essentially on quantifying whether a tumour was, or was not, estrogen dependent-a situation that had lasted for a century ${ }^{[1]}$. A quiet revolution has taken place so that in modern times breast cancer is characterized by its molecular and clinical heterogeneity. Molecular classification of breast cancer is based on gene expressing profile, theysubgroup [luminal A, luminal B, HER2, and basal like] have distinct gene expression pattern and phenotypical characteristics. TNBC shares phenotypical features with basal like breast cancer, which is in turn the most aggressive and with worse outcome. There is a growing evidence of the heterogeneity of such entity on the molecular level that may cause discrete outcomes. Breast cancer is a heterogeneous disease, encompassing a number of distinct biological entities that are associated with specific morphological and immunehistochemical features and clinical behavior. Triple-negative breast cancer (TNBC) accounts for 10-20\% of all breast carcinomas. Triple-negative cancers have a tendency to affect Pre-menopausal and African-American/Hispanic women more frequently ${ }^{[5]}$.

Triple-negative tumors (estrogen receptor (ER), progesterone receptor (PR) and HER-2 negative) have aggressive clinical behavior and poor prognosis. Most TNBC shows a basal-like phenotype ${ }^{[4]}$.More advanced stage at diagnosis and larger median tumor size are characteristic for TNBC. Triple-negative tumorshave high histological and nuclear grade, high mitoticindex, low local relapse rate, and more distant recurrence ${ }^{[5] .}$ 
Relapses and deaths commonly occur within the first 5 years following diagnosis ${ }^{[2,7]}$. Breast cancer survival at 3 and 10 years is correlated closely with histological grade, size, and lymph node involvement. In this study, we try to investigate some demographic, clinical, and pathological characteristics of the triple-negative breast cancers in Northern part of INDIA.

\section{Patients And Methods}

Study Design: Hospital based retrospective, descriptive type of observational study.

Study Place: Dept. of General Surgery SMS hospital Jaipur Rajasthan.

Study Population: 338 cases of diagnosed breast cancer.

Statistical Analysis: Descriptive statistics

This analysis included women with diagnosed breast cancer at SMS hospital Jaipur.

Patient demographics were obtained.

Tumors were staged according to the TNM criteria.

The data on ER, PR, andHER2/neu was obtained through standard clinical testing, Tumors scored as 2 were not included in this study. We further categorized the patients as triple-negative if they were negative for estrogen receptor, progesterone receptor, and Her $2 /$ neu.

III. Statistical analysis:

Table 1: Patient characteristics

\begin{tabular}{|l|l|l|l|}
\hline \multirow{4}{*}{ Age } & & $\mathbf{N}$ & $\%$ \\
\hline \multirow{2}{*}{ Menstrual status } & $\mathbf{2 5}$ to 45 years & 17 & $56.6 \%$ \\
\cline { 2 - 4 } & $\mathbf{4 6}-\mathbf{6 0}$ years & 9 & $30 \%$ \\
\cline { 2 - 4 } & $>60$ years & 4 & $13.3 \%$ \\
\hline \multirow{2}{*}{ Laterality } & Pre Menopause & 18 & $60 \%$ \\
\cline { 2 - 4 } & Post Menopause & 12 & $40 \%$ \\
\hline \multirow{2}{*}{ Locality } & Right & 14 & $46.6 \%$ \\
\cline { 2 - 4 } & Left & 16 & $53.3 \%$ \\
\hline \multirow{2}{*}{ Parity } & UOQ & 16 & $53.3 \%$ \\
\cline { 2 - 4 } & REST & 14 & $46.6 \%$ \\
\hline \multirow{2}{*}{ OCP use } & Parity $\square \mathbf{3}$ & 19 & $63.3 \%$ \\
\cline { 2 - 4 } & Parity $<3$ & 11 & $36.6 \%$ \\
\hline \multirow{2}{*}{ Smoking history } & Yes & 5 & $16.6 \%$ \\
\cline { 2 - 4 } & No & 25 & $83.4 \%$ \\
\cline { 2 - 4 } & Yes & 3 & $10 \%$ \\
\cline { 2 - 4 } & No & 27 & $90 \%$ \\
\hline
\end{tabular}

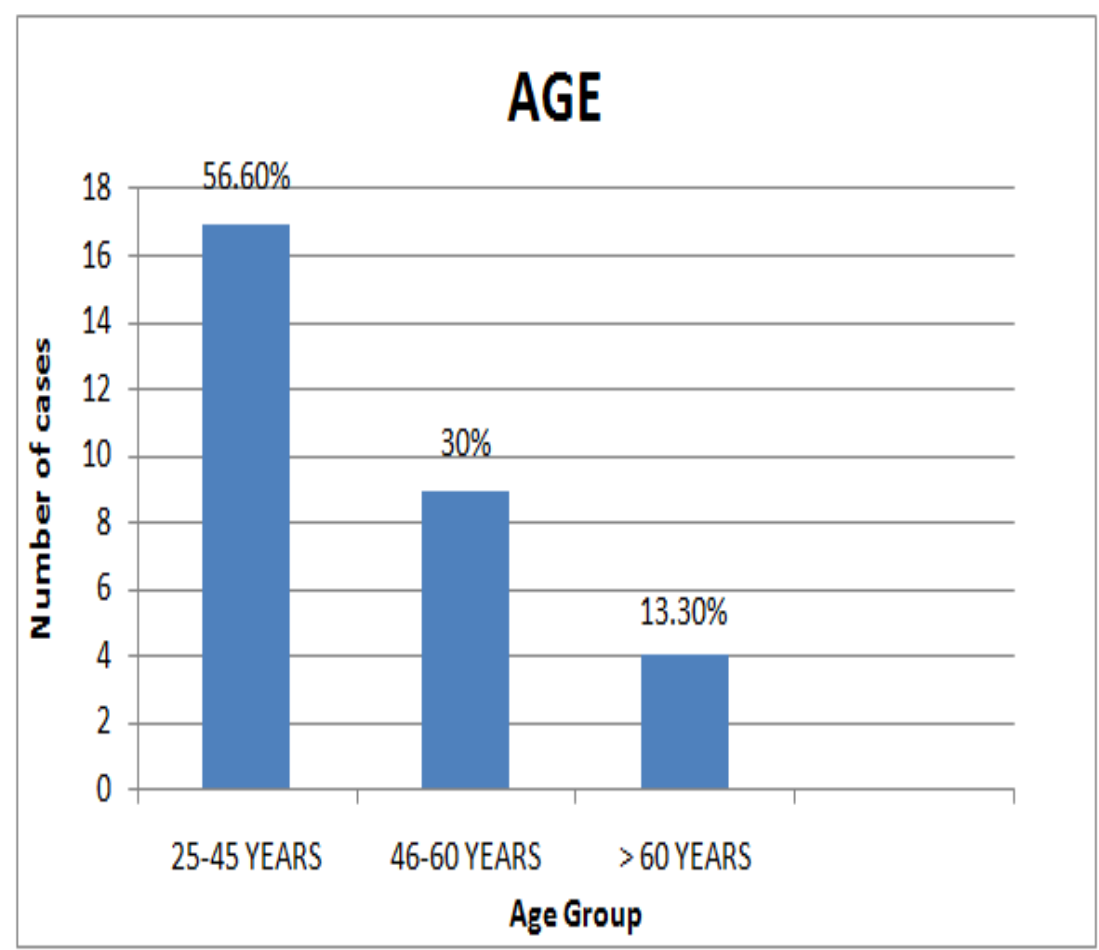




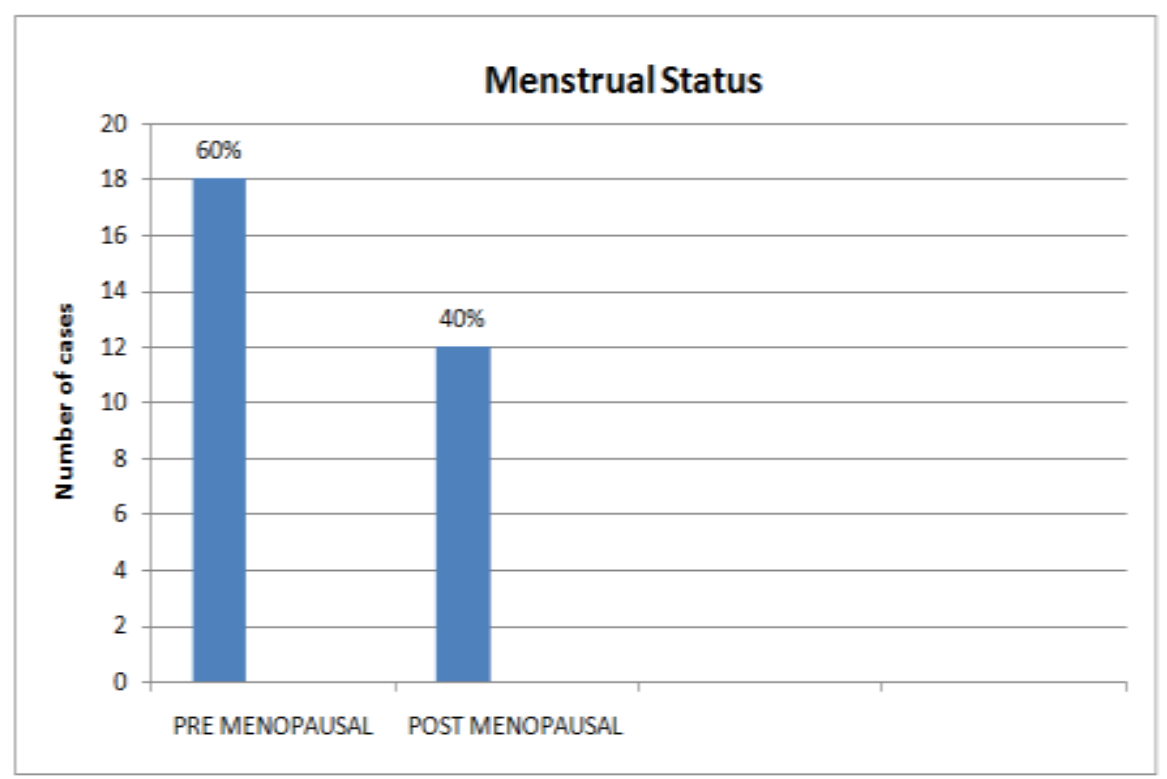

Table 2: Histological Pattern of TNBC:

\begin{tabular}{|l|l|l|l|}
\hline Characteristic & & $\mathbf{N}$ & $\mathbf{\%}$ \\
\hline Histological type & IDC & 29 & $96.6 \%$ \\
\hline & OTHER & 1 & $3.3 \%$ \\
\hline
\end{tabular}

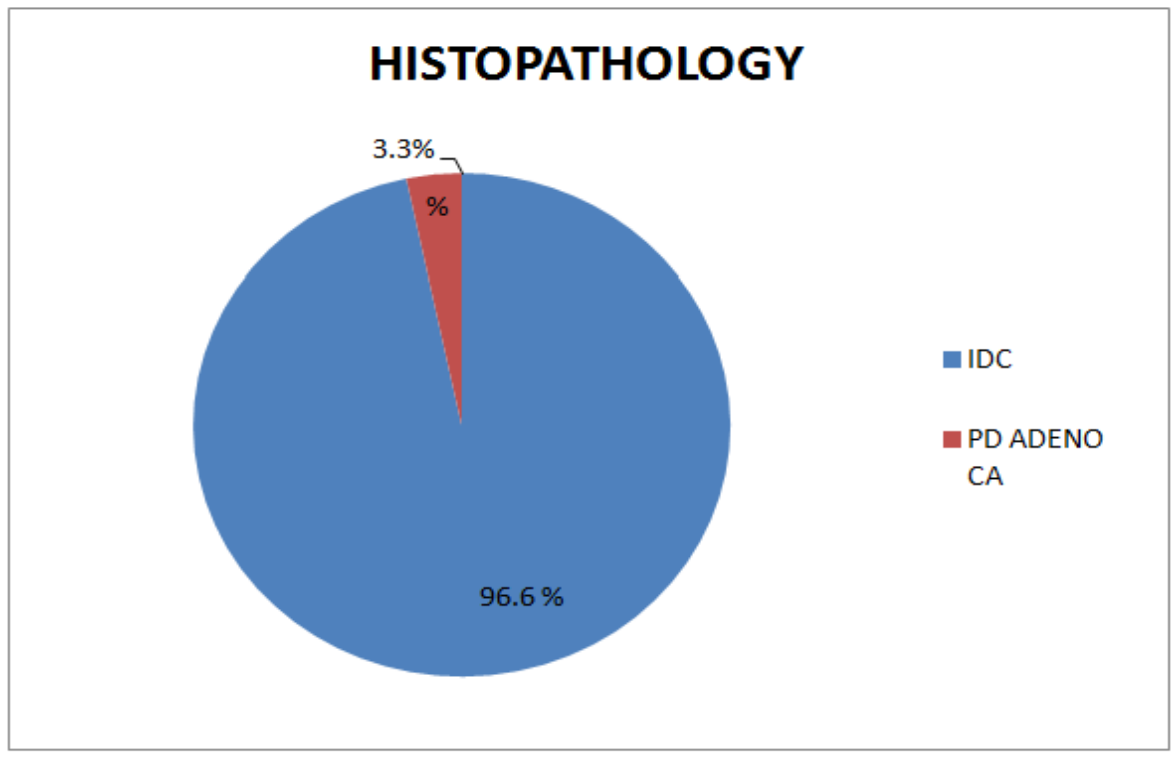

Table 3: Tumor characteristics

\begin{tabular}{|c|c|c|c|}
\hline Characteristics & & $\mathbf{N}$ & $\%$ \\
\hline \multirow{4}{*}{ T STAGE } & T1 & 2 & $6.6 \%$ \\
\hline & T2 & 17 & $56.6 \%$ \\
\hline & T3 & 8 & $26.6 \%$ \\
\hline & T4 & 3 & $10 \%$ \\
\hline \multirow{4}{*}{ N STAGE } & No & 5 & $16.6 \%$ \\
\hline & N1 & 22 & $73.3 \%$ \\
\hline & $\mathbf{N 2}$ & 3 & $10 \%$ \\
\hline & N3 & 0 & $0 \%$ \\
\hline \multirow{4}{*}{ TNM STAGE } & 1 & 1 & 3.3 \\
\hline & $2^{\text {nd }}$ & 17 & $56.6 \%$ \\
\hline & $3^{\text {rd }}$ & 11 & $36.6 \%$ \\
\hline & $4^{\text {th }}$ & 1 & $3.3 \%$ \\
\hline \multirow{2}{*}{$\begin{array}{ll}\text { METASTATIS } & \text { AT } \\
\text { PRESENTATION } & \\
\end{array}$} & YES & 1 & $3.3 \%$ \\
\hline & NO & 29 & $96.6 . \%$ \\
\hline
\end{tabular}



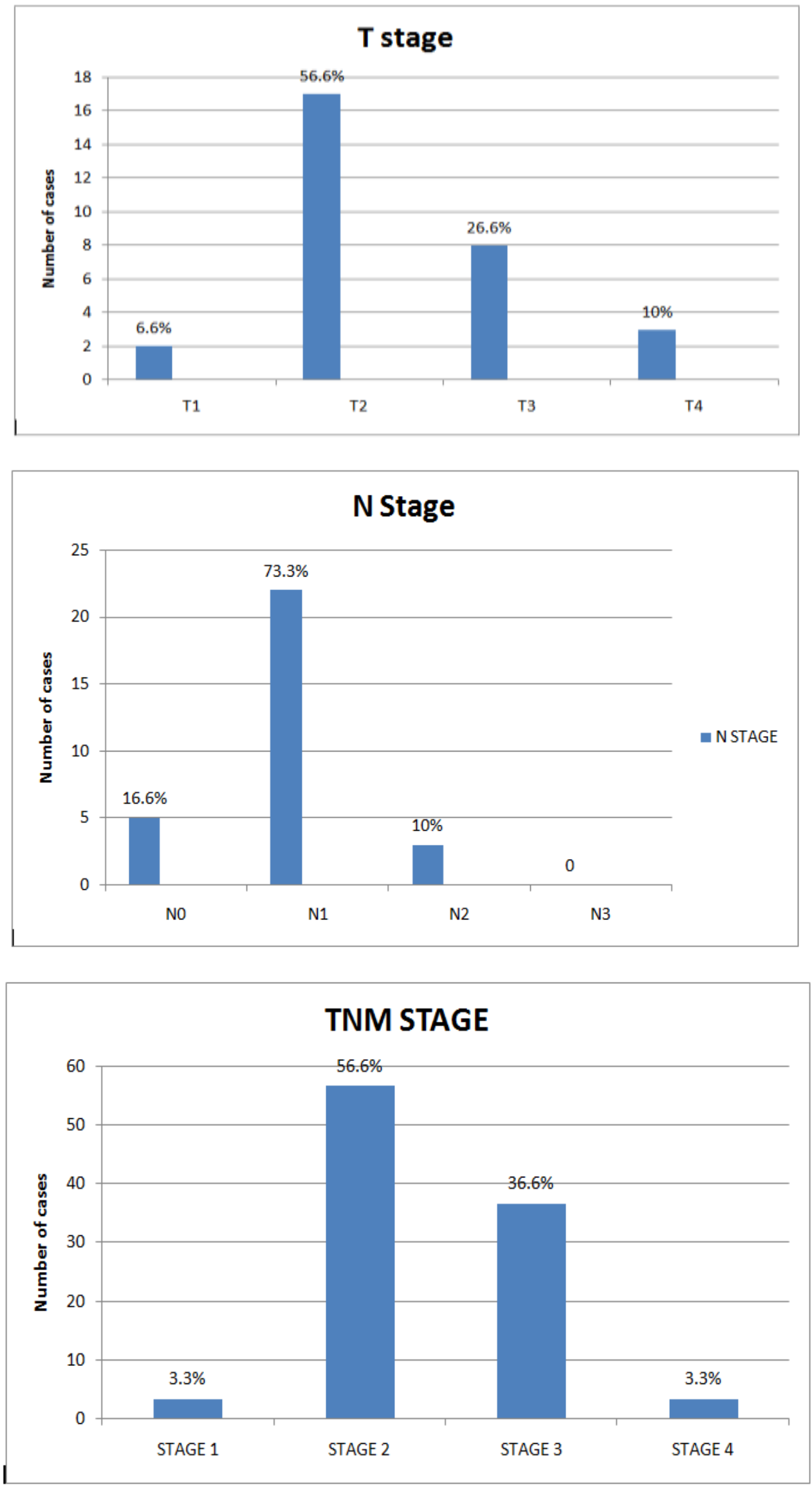
Clinicopathological Features Of Triple Negative Breast Cancer: A ...

Table 4: Comparison with other studies

\begin{tabular}{|c|c|c|c|c|c|c|}
\hline Studies & $\begin{array}{l}\text { Prevalence } \\
(\%)\end{array}$ & Mean age & $\begin{array}{l}\text { Post } \\
\text { Menopausal } \\
(\%)\end{array}$ & $\begin{array}{l}\text { Parity } \square 3 \\
(\%)\end{array}$ & OCP $(\%)$ & $\begin{array}{l}\text { Smoking } \\
\text { history }(\%)\end{array}$ \\
\hline Present study & 9.7 & 46.8 & 40 & 63.3 & 16.6 & 10 \\
\hline Kuwait $^{33}$ & 12.2 & 18 & 39 & 50.2 & 44 & 7.7 \\
\hline Lebanon $^{34}$ & 9.3 & 52 & 52 & & & \\
\hline Turkey $^{11}$ & 10.6 & 44 & 30 & & 35 & \\
\hline Singapore $^{17}$ & 11 & 53 & & & & \\
\hline Korea $^{8}$ & 16 & 45 & & & & \\
\hline Japan $^{26}$ & & 56 & & & & \\
\hline Mayo $^{35}$ Clinic & & 59.7 & & & & \\
\hline Bauer et. ${ }^{16}$ al. & & 50 & & 664.6 & & \\
\hline Dent et.al. $^{36}$ & & 50 & & & & \\
\hline Phipps ${ }^{19}$ et.al. & & & & 57 & 55 & \\
\hline Kwan ${ }^{18}$ wt.al. & & & & 34 & 72 & 49 \\
\hline
\end{tabular}

\section{Discussion}

The demographic, clinical and pathological features of the patients with TNBC are different from other molecular type of cancer breast. The prevalence of TNBC in the northern part of India [Rajasthan] is $9.7 \%$ as shown in our study, Korea [16\%] seems to have the highest and Lebanon [9.3\%] the lowest ${ }^{8,34}$ prevalence. In comparison to other breast cancer subtypes, pt of TNBC presents earlier than other molecular type of breast cancer, and in premenopausal women. In our study the average age of TNBC presentation was 46.8 years. Korea and Turkey have the youngest cohort the TNBC [44-45years], ${ }^{8,}{ }^{11}$ While Japan has the oldest [mean age was 56 years]. ${ }^{26}$ However many studies documented 50 years as the mean age at diagnosis of TNBC. $60 \%$ of the pt were Premenopausal which is comparable to the study done in Turkey [70\%], ${ }^{11}$ and $48 \%$ in Lebanon In our study $16.6 \%$ patients gave history of oral contraceptives [OCP] as compared by $72 \%$ in Kwan et. $\mathrm{al}^{18}, 44 \%$ in Kuwait $^{33}, 55 \%$ in Phipps et al study ${ }^{19}$ and $35 \%$ in the Turkish study. ${ }^{11}$ In our study $10 \%$ patients gave history of smoking as compared by $7.7 \%$ in Kuwait $^{33}$ and $49 \%$ in Kwan et al. In TNBC more than $90 \%$ exhibit an invasive ductal histology [IDC]. In our study, $96.6 \%$ pts were of IDC which is almost comparable to that of Singapore and Japan [93\% and $95 \%$ respectively]. At diagnosis, TNBCs are commonly presents with larger tumor size. In our study, the mean tumor size was $3.5 \mathrm{~cm}$ in TNBC group near about to that in dent et al ${ }^{36}$ and Kuwait ${ }^{33}$. It was smaller $[2 \mathrm{~cm}]$ in Tawfik et al. ${ }^{17}$ study.

\section{Results}

Total 338 breast cancer patients were studied, out of them 30 patients [9.7] were found to have TNBC. Age of presentation of triple negative breast cancer is earlier than other sub groups of breast cancer. Pre menopausal women with breast cancer are more likely to have TNBC. Triple negative group have more aggressive behavior and present at more advanced stage.

\section{They are mainly IDC.}

Smoking, OCP intake and parity do not have any extra impact on triple negative type of breast cancer. The presentation in UOQ is more as compared to other quadrant which is same with other group of breast cancer. So TNBC is a different entity than other breast cancer and is an area for further research to develop novel treatment.

\section{Bibliography}

[1]. BeatsonGT. On the treatment of inoperable cases of carcinoma of the mamma: suggestions for a new method of treatment, with illustrative cases, Lancet, 1896, vol. 148 (pg. b104-b107)https://doi.org/10.1016/S0140-6736(01)72307-0

[2]. Reis-Filho JS, Tutt AN. Triple negative tumours: a critical review. Histopathology. 2008; 52:108-18.

[3]. Arslan C, Dizdar O, Altundag K. Pharmacotherapy of triple-negative breast cancer. Expert OpinPharmacother. 2009;10:2081-93.

[4]. Irvin WJ Jr, Carey LA. What is triple-negative breast cancer? EurJ Cancer. 2008;44:2799-805.

[5]. Carey LA, Perou CM, Livasy CA, et al. Race, breast cancer subtypes, and survival in the Carolina breast cancer study. Jama. 2006;295:2492-502.https://doi.org/10.1001/jama.295.21.2492Google ScholarCrossRefSearchADSPubMed

[6]. Stockmans G, Deraedt K, Wildiers H, Moerman P, ParidaensR.Triple-negative breast cancer. CurrOpinOncol. 2008;20:614-20.

[7]. Tischkowitz M, Brunet JS, Begin LR, et al. Use of immunohistochemicalmarkers can refine prognosis in triple negative breastcancer. BMC Cancer. 2007;7:134.

[8]. Ghosn M, Hajj C, Kattan J, et al. Triple-negative breast cancerin Lebanon: a case series. Oncologist 2011;16(11):1552-6 [Epub2011 Oct 21].

[9]. Park YH, Lee SJ, Cho EY, et al. Clinical relevance of TNMstaging system according to breast cancer subtypes. AnnOncol2011;22(July 7):1554-60 [Epub 2011 Jan 17]. 
[10]. Carey LA, Perou CM, Livasy CA, et al. Race, breast cancersubtypes, and survival in the Carolina Breast Cancer Study.JAMA2006;295:2492-502.

[11]. Aksoy S, Dizdar O, Harputluoglu H, AltundagK.Demographic, clinical, and pathological characteristics ofTurkish triple-negative breast cancer patients: single centerexperience. Ann Oncol2007;18(November 11):1904-6.31

[12]. Rhee J, Han SW, Oh DY, et al. The clinicopathologiccharacteristics and prognostic significance oftriple-negativity in nodenegative breast cancer. BMC Cancer2008;8:307, http://dx.doi.org/10.1186/1471-2407-8-307.

[13]. Billar JA, Dueck AC, Stucky CC, et al. Triple-negative breastcancers: unique clinical presentations and outcomes. AnnSurgOncol2010;17(Suppl. 3):384-90 [Epub 2010 Sep 19].

[14]. Aksoy S, Dizdar O, Harputluoglu H, AltundagK.Demographic, clinical, and pathological characteristics ofTurkish triple-negative breast cancer patients: single centerexperience. Ann Oncol2007;18(November 11):1904-6.31.

[15]. Ishikawa Y, Horiguchi J, Toya H, et al. Triple-negative breastcancer: histological subtypes and immunohistochemicalandclinicopathological features. Cancer Sci2011;102(March3):656-62, http://dx.doi.org/10.1111/j.13497006.2011.01858.x.

[16]. Bauer KR, Brown M, Cress RD, Parise CA, CaggianoV.Descriptive analysis of estrogen receptor (ER)-negative,progesterone receptor (PR)-negative, and HER2-negativeinvasive breast cancer, the so-called triple-negativephenotype: a population-based study from the CaliforniaCancer Registry. Cancer 2007;109:1721-8.18.

[17]. Tawfik O, Davis K, Kimler BF, et al. Clinicopathologicalcharacteristics of triple-negative invasive mammarycarcinomas in African-American versus Caucasian women.AnnClin Lab Sci2010;40(4):315-23 [Fall].

[18]. Kwan ML, Kushi LH, Weltzien E, et al. Epidemiology of breastcancer subtypes in two prospective cohort studies of breastcancer survivors. Breast Cancer Res 2009;11:R31.38.

[19]. Phipps AI, Chlebowski RT, Prentice R, et al. Body size, physicalactivity, and risk of triple-negative and estrogenreceptor-positive breast cancer. Cancer EpidemiolBiomarkersPrev2011;20(March 3):454-63 [Epub 2011 Mar 1].

[20]. Lin C, Chien SY, Chen LS, et al. Triple negative breastcarcinoma is a prognostic factor in Taiwanese women. BMCCancer2009;9(June): 192.33.

[21]. Fulford LG, Easton DF, Reis-Filho JS, et al. Specificmorphological features predictive for the basal phenotype ingrade 3 invasive ductal carcinoma of breast. Histopathology2006;49:22-34,http://dx.doi.org/10.1111/j.1365-2559.2006.02453.x.

[22]. Lakhani SR, Reis-Filho JS, Fulford L, et al. Prediction ofBRCA1status in patients with breast cancer using estrogenreceptor and basal phenotype. Clin Cancer Res2005;11:5175-80.

[23]. Livasy CA, Karaca G, Nanda R, et al. Phenotypic evaluation ofthe basal-like subtype of invasive breast carcinoma. ModPathol2006;19:264-71.

[24]. Tsuda H, Takarabe T, Hasegawa T, et al. Myoepithelialdifferentiation in highgrade invasive ductal carcinomas withlarge central acellular zones. Hum Pathol1999;30:1134-9.

[25]. Tsuda H, Takarabe T, Hasegawa F, et al. Large, centralacellular zones indicating myoepithelialtumordifferentiation in high-grade invasive ductal carcinomas asmarkers of predisposition to lung and brain metastases. Am JSurgPathol2000;24:197-202.45

[26]. Ishikawa Y, Horiguchi J, Toya H, et al. Triple-negative breastcancer: histological subtypes and immunohistochemicalandclinicopathological features. Cancer Sci2011;102(March3):656-62, http://dx.doi.org/10.1111/j.13497006.2011.01858.x.

[27]. Foulkes WD, Brunet JS, Stefansson IM, et al. The prognosticimplication of the basal-like (cyclin E high/p27low/p53+/glomeruloidmicrovascularproliferation+)phenotype of BRCA1-related breast cancer. Cancer Res2004;64:830-5.

[28]. Tian XS, Cong MH, Zhou WH, Zhu J, Chen YZ, Liu Q.Clinicopathologic and prognostic characteristics oftriple-negative breast cancer. Onkologie2008;31:610-4.

[29]. Dogan L, Atalay C, Yilmaz KB, Ozaslan C. Prognosis inhormon receptor negative breast cancer patientsaccordingto ERBB2 status. Neoplasma2008;55:544-8.52

[30]. Chivukula M, Striebel JM, Ersahin C, Dabbs DJ. Evaluation ofmorphologic features to identify "basal-like phenotype" oncore needle biopsies of breast. ApplImmunohistochemMolMorphol2008;16:411-6.54

[31]. Nishimura R, Arima N. Is triple negative a prognostic factorin breast cancer? Breast Cancer 2008;15:303-8.53

[32]. Stark A, Kapke A, Schultz D, Brown R, Linden M, Raju U.Advanced stages and poorly differentiated grade areassociated with an increased risk of HER2/neu positive breastcancer only in white women: findings from a prospectivecohort study of AfricanAmerican and white-Americanwomen. Breast Cancer Res Treat 2008;107:405-14.

[33]. Mohammed S. Fayaza, Mustafa S. El-Sherifya,*, Amany El-Basmyb et al. Clinicopathological features and prognosis of triple negative breast cancer in Kuwait: A comparative/perspective analysis_reports of practical oncology and radiotherapy 19 ( 2014 ) 173-181

[34]. Ghosn M, Hajj C, Kattan J, et al. Triple-negative breast cancerin Lebanon: a case series. Oncologist 2011;16(11):1552-6 [Epub2011 Oct 21].

[35]. Perez EA, Roche PC, Jenkins RB, et al. HER2 testing in patientswith breast cancer: poor correlation between weak positivityby immunohistochemistry and gene amplification byfluorescence in situ hybridization. Mayo Clin Proc2002;77:148-54.

[36]. Dent R, Trudeau M, Pritchard KI, et al. Triple-negative breastcancer: clinical features and patterns of recurrence. ClinCancer Res 2007;13(August 15 Pt 1):4429-34. 